\title{
On the origin of the royal Kongo title ngangula
}

\author{
Koen Bostoen, Odjas Ndonda Tshiyayi \\ and Gilles-Maurice de Schryver
}

\begin{abstract}
This article offers an in-depth historical-comparative linguistic account of the origin and etymology of ngangula. This term is not only a widespread blacksmith term in the Lower Congo region, but also a traditional royal Kongo title attesting to the importance of the blacksmith metaphor in Kongo political ideology. Popular etymology has it that ngangula is related to nganga, reconstructed in Proto-Bantu as *-gàngà and commonly translated as 'medicine-man'. It is argued here that this widely held belief does not stand up to scrutiny. The term ngangula is shown to be derived from the common Bantu verb *pàngud- meaning 'to cut; to separate'. Thanks to a distinctive diachronic sound change, it is even possible to locate quite precisely the term's origin within the Kikongo dialect continuum. Its provenance gives new credibility to an earlier but discarded hypothesis situating the origins of the Kongo kingdom in the eastern part of the Lower Congo, somewhere in-between the Inkisi and Kwango Rivers.
\end{abstract}

\section{Keywords}

Kikongo, Kongo kingdom, sound change, semantic change, African history 


\section{Introduction ${ }^{1}$}

The kingdom of Kongo, which arose in the Atlantic Coast region of Central Africa, is one of the most famous emblems of Africa's past. It entered European history shortly after Portuguese sailors first reached the mouth of the Congo River in 1482. The centralized polity they encountered reminded them of their home kingdom. Regular diplomatic relationships between both states with accompanying exchanges of people, ideas and commodities were soon established. Even though much is known on the rise and fall of the Kongo kingdom from that point in time, especially from the later $16^{\text {th }}$ century onwards, little is clear on its origin and early history before the first contacts with Europe.

In the absence of written records, language has proven to be a rewarding source of history in Africa, especially in conjunction with bodies of evidence from other disciplines yielding historical information, such as archaeology. ${ }^{2}$ Reconstructing history more generally from the history of words is particularly advantageous if one works on Bantu languages. These are of relatively recent origin and therefore still closely related, which facilitates lexical comparison. The abundance of related lexemes manifesting micro-variation in form and meaning across Bantu languages often allows for the reconstruction of etymons in ancestor languages, the seriation of the successive sound changes and semantic shifts as well as the retracing of loanword origins and diffusion paths. As to the pre-colonial history of Central Africa, historians such as Christopher Ehret, Jan Vansina, David Schoenbrun and Kairn Klieman were the first to fully exploit the historical potential of comparative language data (Ehret 1974; Klieman 2003; Schoenbrun 1998; Vansina 1974). Kathryn de Luna and Rhiannon Stephens are historians who started more recently to rely on language data for the reconstruction of African history (de Luna 2008, Stephens 2007, 2009).

Historical linguists, for their part, have only hesitatingly committed themselves to this application of their discipline, also known as the words-and-things method or linguistic palaeontology (Dimmendaal 2011: 334). Unlike historians, who tend to focus on branches of the Bantu family, linguists generally consider the entire Bantu domain. Doing so, they have been mainly concerned with the historical development of specific semantic fields, such as metallurgy, pottery, or cuisine, as well as with the consolidation of the method's foundations (Blench 2009; Bostoen 2005, 2007; de Maret \& Nsuka-Nkutsi 1977; Grégoire 1976; Klein-Arendt 2004; Philippson \& Bahuchet 1994-1995; Ricquier 2013; Ricquier \& Bostoen 2008). Historians are generally more interested in the broader history of a specific region, although some did focus on specific bodies of words pertaining to kinship (Stephens 2009), iron working (Ehret 2001; Vansina 2006), hunting (de Luna 2012) or other subsistence

1. Our thanks go to John Thornton (Boston University), Pierre de Maret (Université libre de Bruxelles), Birgit Ricquier (Royal Museum for Central Africa) and two anonymous reviewers for their feedback on earlier versions of this article. The usual disclaimers apply. 2. This article is part of an ERC-funded research project (StG No. 284126) that aims at contributing to a better understanding of the origins and early history of the Kongo kingdom through an interdisciplinary approach combining historical linguistics and archaeology. For more information, please consult the project website on http://kongoking.org/. 
strategies (Ehret 1967, 1974). Historical linguists and historians have not only been complementing each other rather well in terms of research topics, but also with regard to research objectives and methods. As de Luna et al. (2012: 82) summarize, 'historians seeking to engage with colleagues in their discipline tell stories in which people and communities of speakers are the agents, while linguists might write about the development of languages, words, or technologies without focusing primarily on human agency or historical contingency'. As discussed in more detail elsewhere (Bostoen 2007; Vansina 2009), these different research objectives lead to fundamental differences in the way historians and linguists analyse language data and sometimes to disagreement between the conclusions they draw from the same language data (see for instance Bostoen 2006-2007 with regard to the history of pearl millet in Bantuphone Africa).

In this article, we adhere once more - noblesse oblige - to the typical approach of historical linguists by focussing on the origin of one specific royal Kongo title, i.e. ngangula, which co-exists with others such as ntinu and ntotila (Vansina 1990: 156). In the pages that follow, we present a detailed historical linguistic study of the term's etymology, semantic evolution and spread. Such a systematic study has never been undertaken. Etymologies proposed so far have been speculative and do not bear the test of historical-comparative linguistic examination. As a consequence, the historical information that this royal title may hold in terms of royal Kongo history was overlooked.

Royal titles can teach us more about kingship origins and if not indicative of kingship origins themselves, they may reflect how political leadership was conceptualized and where these ideas came from. In an etymological study of the Hittite king's titles tabarna/labarna, which started out as the personal name of the first two Hittite rulers in the early $17^{\text {th }}-16^{\text {th }}$ century B.C., Soysal (2005) refers to the comparison with the Latin Caesar, an opinio communis in Hittotology since the very early years. This Roman imperial attribute also started out as a personal name before becoming the title of Roman emperors with its later reflection in German Kaiser and Russian Czar, and was understood as "dominant ruler". Oğuz Soysal furthermore demonstrates that tabarna had its origin in the language of the Hattians who inhabited this region in Anatolia before the Indo-European speaking Hittites arrived. In the present article, using historical-comparative linguistic evidence, we argue in a similar way, on the basis of phonological evidence, that the royal Kongo title ngangula can only have originated in one specific dialectal zone of what is today the large Kikongo dialect continuum (H10). Interestingly enough, this area is neither the kingdom's customary centre of power, i.e. the capital at Mbanza Kongo in current-day northern Angola, nor is it situated in what is traditionally believed to be the homeland of Kongo rulers north of the Congo River, i.e. the polity known as Bungu or Vungu, close to the sources of the Shiloango River in current-day Mayombe (DRC) (Thornton 2001; Vansina 1963).

Moreover, beyond the question of origins, the fact that this word became a traditional king's title attests to the prominence of the blacksmith metaphor in Kongo political ideology: ngangula a Kongo literally means 'blacksmith of Kongo' (Balandier 1965: 28; Monnier 1966: 25; Wannyn 1961: 10). Political power and blacksmithing are closely linked phenomena in many African societies, 
especially so in Bantu-speaking Central Africa (de Maret 1985; Dupré \& Pinçon 1997; Herbert 1993; Kriger 1999). In several notorious and historically related pre-colonial kingdoms, such as Tio, Loango and Kongo, this connection was so strong that chiefs and blacksmiths were one and the same at certain times and in certain places. The blacksmith is unmistakably a highly significant symbol in Kongo political ideology (de Heusch 2000; Mac Gaffey 2000; Thornton 1993). We claim in the present article that this close connection between traditional iron working and leadership in Central Africa, the so-called 'smith's myth' (de Maret 1980, 1985), accounts for the fact that ngangula did not entirely wipe out the pre-existing and common Bantu blacksmith term reconstructed as *-túdì. The latter noun did not have the political connotations of ngangula, at least not amongst the Kongo people.

In Section 2, we first assess the antiquity of the term ngangula on the basis of its present-day geographic distribution among Bantu languages. In Section 3, we examine different possible etymologies of ngangula in order to retain the most plausible. In Section 4, we discuss how the origin and distribution of ngangula reflects the association between blacksmith ideology and Kongo kingship. In Section 5, we assess to which extent our findings on ngangula may contribute to the debate on the origins of the Kongo kingdom. Conclusions are presented in Section 6.

\section{Present-day geographic distribution and time depth of ngangula}

The oldest attestation of the term ngangula known to us occurs in the manuscript called Vocabularium Latinum, Hispanicum, e Congense. This vocabulary is the oldest surviving lexicographical source of Kikongo, and indeed of any Bantu language. It dates back to 1652 and was handwritten by the Flemish Capuchin missionary Joris van Gheel who certainly was not its (sole) author (cf. De Kind et al. 2012). In this manuscript, a lemma in Latin is typically followed first by its translation into Spanish (although at times this slot remains empty) and second by one or more translation equivalents in Kikongo. On page 47 of the manuscript, as the excerpt in Figure 1 shows, the Latin lemma 'incus udis's, i.e. 'anvil(s)', is followed by the Spanish translation equivalent 'ayunque'4, corresponding to present-day yunque, and is translated in Kikongo as both etari ri(?) ngangula and munbanda ançúndú. The word in-between etari and ngangula is not easy to decipher, but its function must be that of a genitival connector, which is very common in Bantu languages. The paraphrase literally means 'the stone of the smith'. In their retranslated and revised edition of the Vocabularium Congense, van Wing and Penders (1928: 26) cite this compound term under the lemma e-tari as __ ria ngangula. The connector ria is certainly not what is visible in-between the head noun and the modifier in the manuscript, but this is probably due to the folding of the page. We possibly see the first two letters $<\mathbf{r i}>$ with a hazy dot above the $<\mathbf{i}>$.

3. The genitive of Latin incus is incudis.

4. In the $17^{\text {th }}$ century form, the feminine article was agglutinated to the noun. This variant disappeared later on (Eugeen Roegiest (Ghent University) pers. comm.). 


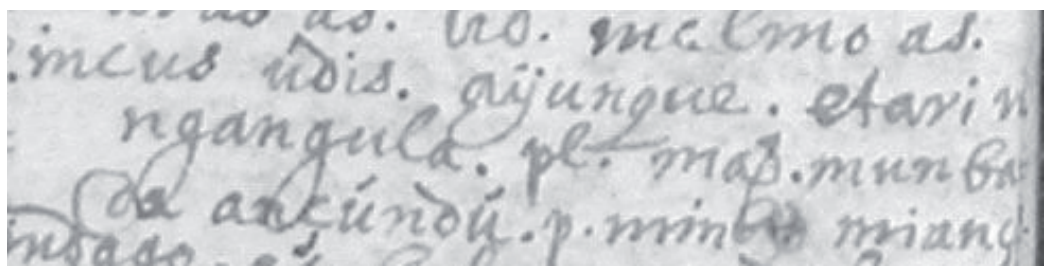

Figure 1: Lemma 'incus udis' in the Vocabularium Congense (Van Gheel 1652)5

Thanks to its occurrence in the Vocabularium Congense (Van Gheel 1652), we know that the term ngangula was already commonly used in the southern part of the Kikongo dialect cluster in the first half of the $17^{\text {th }}$ century. It is generally believed that Van Gheel actually copied from earlier lexicographic work of Capuchin fellows, in which Manuel Roboredo, a priest of mixed Kongo-Portuguese descent ordained in 1637, played a pivotal role (Hildebrand 1940; Nsondé 1995; Thornton 2011b). The term ngangula is observed in other lexicographical sources from the same area but from later periods, i.e. the late $19^{\text {th }}$ to late $20^{\text {th }}$ century, as shown in (1). It has been reported in the three main Kikongo varieties spoken in Angola, i.e. Kisikongo, Kisolongo and Kizombo. Kisikongo, also known as Kisansala, is spoken in the wide vicinity of Mbanza Kongo, the former capital of the Kongo kingdom. Kisolongo is spoken along the coast, amongst others in the vicinity of the important trading port Mbanza Soyo, which used to be one of the kingdom's provincial capitals and was often in fierce competition with Mbanza Kongo. This variety extends into the south-western part of the Lower Congo Province of the DRC. Kizombo is spoken to the east of Mbanza Kongo up to the Angolan province of Uíge. It also extends into the south-eastern part of the Lower Congo Province of the DRC. We did not find an attestation of ngangula or of any other blacksmith term in the Angolan Kikongo variety known as Tsotso (Baka 1992).

(1) Kisikongo ngangula

Kisolongo ngângula

Kizombo ngaángula 'worker (in metal), smith, blacksmith, person skilled in smith work' (Bentley 1887: 371)

'ferreiro' (Tavares 1915: 26)

'blacksmith'

(Carter \& Makondekwa 1987: 114)

The geographic distribution of ngangula is not restricted to the Kikongo varieties from Northern Angola. As shown in (2), it also occurs in several varieties spoken in the Lower Congo Province of the DRC (2a), in Cabinda (2b) and in the southern part of the Congo Republic (2c).

5. A scan of the Vocabularium Congense was kindly put at our disposal by Cécile Fromont (University of Chicago). 
a. Kimanyanga ${ }^{6}$ ngangula

$\begin{array}{lll}\text { Kintandu } & \text { ngangula } & \text { 'blacksmith' } \\ \text { Kinkanu } & \text { ngángúla } & \text { 'forgeron' } \\ \text { Kindibu } & \text { ngangula } & \text { 'forgeron' } \\ \text { Kiyombe } & \text { ngaangúla } & \text { 'artisan' } \\ & \text { ngangula } & \text { 'artisan' } \\ \text { b. Fiote9 } & \text { ngangoula } & \text { 'forgeron' } \\ \text { Iwoyo }{ }^{10} & \text { ngangula } & \text { 'blacksmith' } \\ \text { c. Kilaari } & \text { ngà:ngùlá } & \text { 'forgeron' } \\ & \text { ngangula } & \text { 'un forgeron' } \\ \text { Kihangala } & \text { ngá:ngùlà } & \text { 'forgeron' } \\ \text { Civili } & \text { ngangul' } & \text { 'forgeron' }\end{array}$

'serrurier, forgeron, ouvrier en métal, pers. habile en ciselure; artisan' (Laman 1936: 684)

(Guinness 1882: 24) ${ }^{7}$

(Daeleman 1983: 379)

(Van Damme 1998: 1140)

(Coene 1960: 64)

(De Grauwe 2009: 81)

(Bittremieux 1922: 476)

(Visseq 1889: 64)

(Volavka 1998: 144)

(Jacquot 1982b: 252)

(Nsondé 1999: 116)

(Nkouanda 1997: 98)

(I.LA.LOK 2008: 142)

Both the data in (2) and the map on page 59 show that the blacksmith term in question is well distributed within the Kongo dialect continuum. It occurs in southern (Kisikongo, Kisolongo), southeastern (Kizombo), eastern (Kintandu, Kinkanu), western (Kiyombe, Iwoyo, Fiote, Civili), central (Kindibu, Kimanyanga), northern (Kihangala) and northeastern (Kilaari) varieties. It also seems to have made its way into the vehicular Kongo language, also known as Kituba, Monokutuba or Kikongo ya Leta (Fehderau 1992: 186; Swartenbroeckx 1973: 416). It has not been found in several documented Kikongo varieties of the Congo Republic, simply because the sources available to us do not include a blacksmith term, as in Kikamba (Bouka 1989) and Kidondo (Mfoutou 1985), or because the languages have a different blacksmith term, as in Kibembe. In Kibembe, the blacksmith is called mùtsúlì (Jacquot 1962: 238) or mutsuri (Philippson \& Boungou 1999: 87). Ngoie-Ngalla (1989: 193) reports mutsuri and kissudi among the Kongo of the Niari. These cognate terms stem from the common Bantu blacksmith root *-túdì (Bastin et al. 2002). As we will discuss below, this term co-exists with ngangula in several Kikongo varieties.

6. The Central Kongo variety, which Laman also calls 'Mazinga dialect', was the one spoken in the vicinity of the Mukimbungu mission station in the Luozi-Manianga area on both sides of the Congo River. It corresponds to the present-day variety known as Kimanyanga.

7. Guinness (1882) documents the Central Kongo variety spoken in the Cataract region below Pool Malebo, formerly known as Stanley Pool.

8. As a specific Kiyombe blacksmith term, Bittremieux (1922: 476) mentions the paraphrase ngangula ufulanga bisengo. The noun bisengo meaning 'iron' can also be added to ngaangula in Kintandu (André Makokila pers. comm.).

9. Fiote means 'black person' in Kikongo; Visseq (1889) used the label to refer to the variety of Kikongo which he documented at the end of the 19th century in the vicinity of the Landana mission in present-day Cabinda where the small coastal kingdom of Kakongo was located.

10. Iwoyo is the variety of Kikongo spoken in the former kingdom of Ngoyo in present-day Cabinda, south of Kakongo and just north of the Congo estuary. It is also spoken in the area between Kanzi Lusila and Muanda in the Lower Congo Province of the DRC (KongoKing fieldwork 2012). 


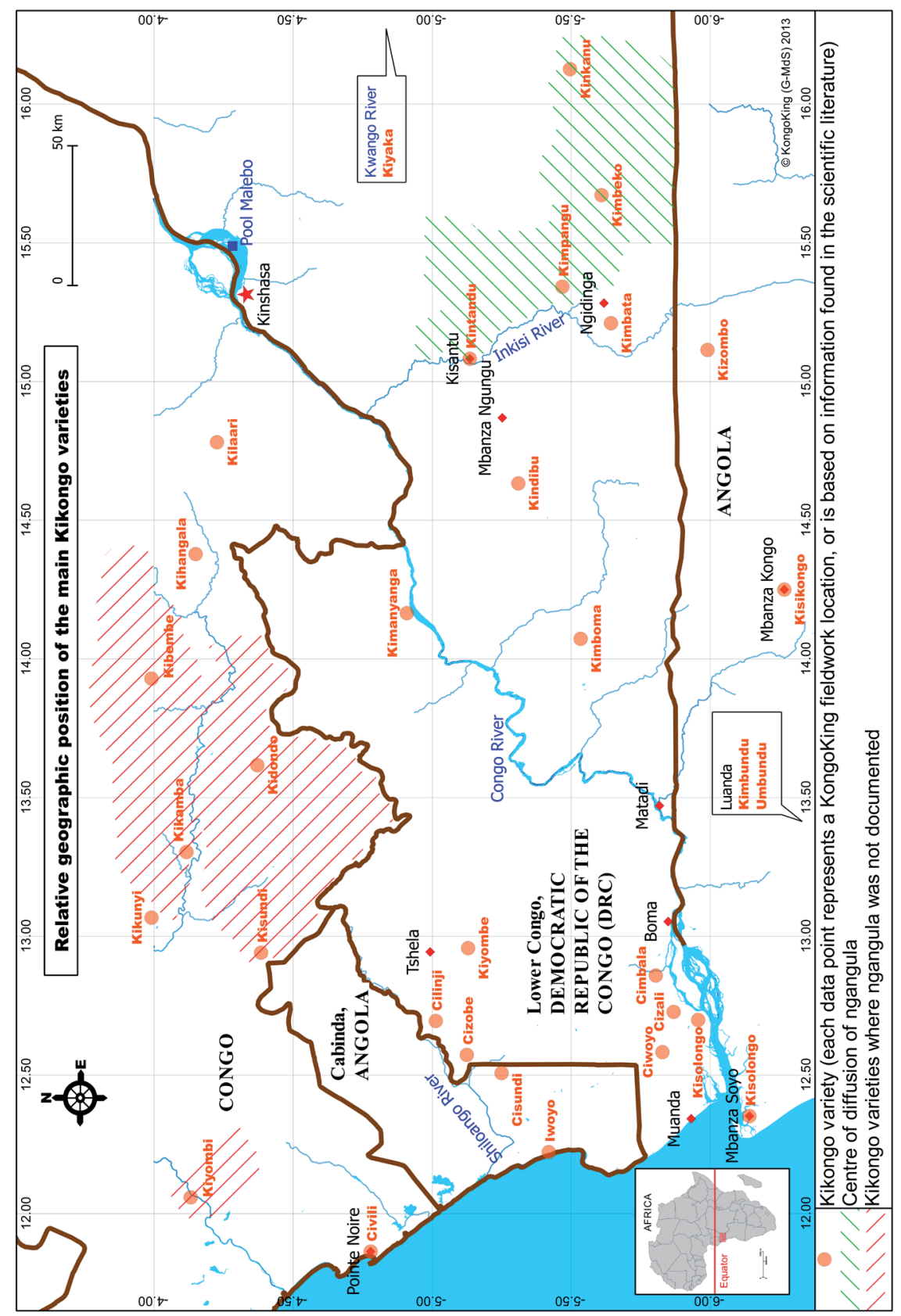


The geographic distribution of ngangula is actually not restricted to the Kikongo language group. The term is also attested in some neighbouring languages, as illustrated in (3).

$$
\begin{aligned}
& \text { Kiyaka (H31) ngáángúlá 'forgeron' (Ruttenberg 2000: 257) } \\
& \text { Kimbundu (H21)ngangula 'forgeron' (Nsondé 2011: 124) } \\
& \text { ngangula 'ferreiro' (da Silva Maia 1961: 298) } \\
& \text { Umbundu (R11) kángula 'smith’ (Fodor \& Magyar 1983: 189) } \\
& \text { ongangula 'ferreiro' (Le Guennec \& Valente 1972: 278) }
\end{aligned}
$$

To the east of Kikongo, ngangula is attested in Kiyaka (Devisch 1993: 69), spoken in the neighbouring Kwango area. Plancquaert (1971: 17) reports relics of blacksmithing clans among Ngongo and Tsamba people from the Kwango region, one of them being called Swa Ngāngula 'Sir Blacksmith'. According to Ndonda Tshiyayi (2004-2005), the Mbala and Hungana people from the same region also use ngangula to refer to the blacksmith. To the south of Kikongo, the distribution of this term extends to Kimbundu and Umbundu in Angola, where it co-exists with other blacksmith terms. In Kimbundu, it co-occurs with mùsùdì (< *-túdì) (da Silva Maia 1961: 298; Nsondé 2011: 124). In Umbundu, ochilengele has also been reported (Le Guennec \& Valente 1972: 278).

No attestations were found in more northerly languages. From a wider Bantu perspective, ngangula definitely is a relatively late lexical innovation. It dates back to at least the $17^{\text {th }}$ century, since it is attested in the Vocabularium Congense, but it could well be older.

One thus notices that the Kongo area is central in-between the term's more eastern and southern distribution zones. In this regard it is important to know that from at least the beginning of the $17^{\text {th }}$ century Kongo's capital, Mbanza Kongo, was in the midst of a long-distance trade route that connected the market of Okango in the Kwango area with Luanda southwest (Vansina 1962). Add to this that Kongo was an important cultural centre in the wider area and it is not hard to assume that this new term gradually diffused from this centre of innovation or focal area to more peripheral relic areas as a classical process of dialectal diffusion (cf. Andersen 1988). Below we show that diachronic phonological evidence indeed points towards such a scenario.

Compared to the common Bantu blacksmith root *-túdì, the geographic distribution of ngangula is very limited. Moreover, ngangula did not wipe out this older Bantu deverbative noun, derived from *-túd- 'to hammer, forge' (Bastin et al.2002). Not only does ngangula not occur in several northern Kikongo varieties, it did not even supplant *-túdì elsewhere. Several of the Kikongo varieties attesting ngangula also have a reflex of *-túdì or another deverbal noun derived from the same verb *-túd-, as shown in (4).

$$
\begin{array}{lll}
\text { Kimanyanga mufúdi } & \begin{array}{l}
\text { 'celui qui travaille avec le marteau, forgeron' } \\
\text { (Laman 1936: 595) }
\end{array} \\
\text { Kintandu } & \begin{array}{l}
\text { mfúla } \\
\text { mfúdi }
\end{array} & \begin{array}{l}
\text { 'qui forge, travaille les métaux' (Laman 1936: 555) } \\
\text { 'forgeron' (Laman 1936: 555) }
\end{array}
\end{array}
$$




$\begin{array}{lll}\text { N-Kongo } & \text { musúdi } & \text { 'forgeron, serrurier' (Laman 1936: 625) } \\ \text { Fiote } & \text { m'fuzi } & \text { 'forgeron' (Anonyme 1890: 71) } \\ \text { Civili } & \text { nfussi } & \text { 'forgeron' (Derouet 1896: 170) } \\ & \text { nfusi } & \text { 'forgeron' (Loëmbe 2005: 30; Marichelle 1912: 66) } \\ & \text { mònuisi } & \text { 'forgeron' (Laman 1936: 559) } \\ & \text { cífula } & \text { 'forgeron' (Ndamba 1977: 156) }\end{array}$

While a reflex of *-túdì has not been reported in the principal Angolan Kongo varieties as of the late $19^{\text {th }}$ century (Bentley 1887; Carter \& Makondekwa 1987; Tavares 1915), the form mufúri is attested in the $17^{\text {th }}$ century Vocabularium Congense. It is found under the lemma faber argentarius 'silversmith' as part of the genitive construction mufúri a prata, literally 'smith of silver'. Under the same lemma, it co-occurs with the compound noun quifula a prata whose first term is derived from the same verb and has the same morphology as the $20^{\text {th }}$ century blacksmith term reported in Civili by Ndamba (1977: 156) (cf. 4). ${ }^{12}$ In their $20^{\text {th }}$ century rework of the Vocabularium Congense, Van Wing and Penders (1928: 205) report mu-furi 'celui qui travaille avec le marteau, forgeron' and under the same lemma the compound term _ a mprata 'ouvrier qui travaille l'argent'.

\section{Etymology of ngangula}

Several scholars have speculated on the etymology of ngangula. It is most frequently associated with nganga, which is indeed a sound-alike. This common Bantu term is usually translated as 'medicine-man', a translation that does not come up to the mark. Amongst Kongo people, nganga not only refers to an expert in healing. It refers more generally to an expert (Van Wing 1938: 162-163). That is why the noun occurs in numerous compound terms in Kikongo (Laman 1936: 683-684). Following Van Wing (1959: 418-419), Janzen and Arkinstall (1978: 45) enumerate nganga bakulu 'the elder who keeps the ancestor basket and administers the cult of the ancestors (bakulu)', nganga mbwa 'the owner of the dog (mbwa) taken to the cemetery and shown to the ancestors before the hunt', nganga buka (or mbuki) 'any person who knows herbal remedies and treats sufferers without the intervention of consecrated medicines', nganga mpaka a 'quarrelsome individual', and banganga Nzambi 'priests of God', the way Catholic priests came to be called. They also mention nganga lufu referring to 'the blacksmith, literally, "operator of the forge" (lufu), a role that entails many subsidiary minkisi and prohibitions'. It probably was the phonological similarity between this alternative term for the blacksmith and ngangula that led scholars to suggest an etymological link

11. This northern Kongo variety was spoken in the vicinity of Kingoyi in the border area between both Congos (Laman 1936: LXV). It corresponds to the variety currently known as Kihangala spoken in the Mindouli district of Congo-Brazzaville (Nkouanda 1997).

12. In the Vocabularium Congense, $\mathbf{l}$ and $\mathbf{r}$ are in complementary distribution and can thus be considered as allophones of a same phoneme. The grapheme $\mathbf{r}$ is only attested in front of the closed front vowel $\mathbf{i}$. It is still unclear why $\mathbf{r}$ is noted in this phonological context. The sound $\mathbf{r}$ is unattested in southern Kikongo varieties as documented since the end of the $19^{\text {th }}$ century (Bentley 1887; Ndonga Mfuwa 1995; Tavares 1915). Like most other Kikongo varieties, Kisikongo and Kisolongo have $\mathbf{d}$ as allophone of $\mathbf{1}$ in front of $\mathbf{i}$. 
between both terms (Balandier 1965: 100; Janzen \& Arkinstall 1978: 45; N'Sondé 2012: 123; Soret 1959: 49-50). Nevertheless, ngangula can neither be considered as a shortened reproduction of nganga lufu, nor as a noun derived from nganga.

The element -ul- distinguishing ngangula from nganga is reminiscent of the so-called 'separative' or 'reversive' suffix reconstructed as *-ud- in Proto-Bantu (Schadeberg 2003: 77). It is a verb-to-verb extension, meaning that it serves to derive verbs from other verbs. Hence, it cannot be used to derive a noun - in this case ngangula - from another noun - in this case nganga. If there really was an etymological link between both nouns, they could only be derived from a same base verb. Given that the noun stem *-gàngà dates back to Proto-Bantu (Bastin et al. 2002), it should be considered as a noun which Kikongo speakers inherited as such from their ancestors, rather than a noun which Kikongo speakers would have created through deverbative derivation, as Janzen and Arkinstall (Janzen, 1978: 45) assume. They claim that nganga 'derives from the verb vanga ("doer" or "maker")'. This is impossible from a morphophonological point of view, since such a derivation would result in a noun like m̀vángi 'executor, Creator' (Laman 1936: 632), belonging to noun classes $1 / 2$ or mpángu 'work, care, zeal, activity' (Laman 1936: 575), belonging to classes 9/10.

On the other hand, the existence of a noun like ngàngu 'perspicacity, trickery, cunning, wit, foresight, prudence, intelligence, reason, cleverness, wisdom, address, gift, talent, finesse, lie, hypocrisy' (Laman 1936: 684), which resembles ngànga both in shape and meaning and which ends in the deverbative suffix -u, reflex of Proto-Bantu *-o (Schadeberg 2003: 80), suggests that ngànga itself might also be deverbative in origin, even if this origin definitely predates Kikongo, since reconstructed in Proto-Bantu as *-gàngà. Formally speaking, a possible source verb is *-gàng- reconstructed in Proto-Bantu with the meaning 'to tie up' (Bastin et al. 2002; Vansina 1990: 298). At first sight, this meaning does not really seem to tie in with the semantics of ngànga and ngàngu in Kikongo. However, in certain Bantu languages, this verb does mean 'to heal' (Guthrie 1970: 208). Such is not the case in Kikongo, where the reflex of the Proto-Bantu verb *-gàngis -kànga, / $\mathbf{k}$ / being a regular reflex of Proto-Bantu * $\mathrm{g}$ in intervocalic position as opposed to $/ \mathbf{g} /$ in post-nasal position (Laman \& Meinhof 1928-29: 15). In Kikongo, this verb is polysemous, but its different uses can be considered specific instantiations of the verb's original meaning 'to tie up', i.e. 'to attach, close, knot, strap, trap, imprison, arrest, coagulate, etc.' (Laman 1936: 213). The transitive separative verb -kàngula, derived from -kànga, means 'to undo, untie, loosen, solve, dissolve, decompose, open, liberate, deliver, etc.' (Laman 1936: 215), in line with the suffix's fundamental meaning 'movement out of some original position' (Schadeberg 2003: 78). In Christian contexts, it is read as 'to save'.

Interestingly, its intransitive counterpart -kànguka, when combined with the noun nitu 'body', conveys the meaning 'to get better, heal (intr.)'(Laman 1936: 215). Logically, -kàngula nitu would then mean 'to make better, cure, heal (tr.)'. This is in line with the fact that the causative verb -kààngis- means 'to heal' in the closely related Kiyaka language. These facts seem to substantiate the etymological links between the Proto-Bantu verb *-gàng- and the Kikongo nouns ngànga and ngàngu. However, they do not allow to derive the blacksmith term ngangula, neither from 
-kànga, the Kikongo reflex of *-gàng-, nor from its separative derivation -kàngula. Taking into account the smith's powers of transformation (Herbert 1993), a semantic association between iron working and healing is well conceivable. However, ngangula can simply not have been derived from -kàngula as far as concerns phonology. The shift from $\mathbf{n}+\mathbf{k}$ to $\mathbf{n g}$ is not a regular morphophonological change in Kikongo. When a nasal prefix agglutinates to a stem with an initial voiceless stop, this does not lead to the voicing of the stem-initial consonant. The latter is rather simply maintained or gets aspirated, either with or without the loss of the nasal itself (Daeleman 1983; De Grauwe 2009; Laman \& Meinhof 1928-29). Hence, the origin of ngangula must be looked for elsewhere.

As suggested by the separative suffix -ul-, the origin of ngangula must indeed be deverbative. The source verb is correctly identified by Daeleman (1983: 341), i.e. the common Bantu verb reconstructed as "-pàngod- 'to cut; separate' (Bastin et al. 2002). The reflex of this verb in Kintandu is -gaangul- [-yaangul-], not to be confused with -gáángúl- [-Yáángúl-] 'to undo, mutilate, ruin', the separative derivation of the verb -gáang- 'to make, do', which is itself a reflex of the common Bantu verb reconstructed as *-páng- 'act; make' (Bastin et al. 2002). Both verbs are segmentally identical, but tonally distinct, not only in Proto-Bantu, but also in present-day Kikongo. This is the case in the Kintandu variety, as seen above (Daeleman 1983: 341), but also in other varieties. In Kiyombe, for example, the reflex of *-pàngod- is -vaangúla 'to store, put away'. Its surface tone pattern clearly differs from the reflex of *-páng-, i.e. -váángá, 'to make, create, fabricate' and its derived form -váángána 'to prepare oneself' (De Grauwe 2009: 113). In the dictionary of Laman (1936: 1050-1051), describing the Kimanyanga variety, we also observe tone contrast: -vàngula 'to separate, isolate, cut, etc.' vs. -vāngula 'to torment, injure, cripple, etc.'. Hence, ngaangula is not derived from the verb -gáángúl- 'to undo, mutilate, ruin', as Devisch (1993: 69) assumes when he translates it literally as 'the artist which is able to undo someone's secret arts'.

\section{Locating the origin of ngangula by means of diachronic phonology}

It is important to stress that the blacksmith term ngaangula can only be derived from *-pàngud- in a variety where the regular reflex of *p is a velar, as is the case in Kintandu. The grapheme $/ g /$ stands there for the voiced velar fricative $[\gamma]$, when it occurs in between two vowels, and for the voiced velar stop [g] when it is preceded by a non-syllabic nasal. The morphophonological shift $\mathbf{\gamma} \rightarrow \mathbf{g} / \mathbf{N}_{-}$is regular in Kintandu and explains why the stem-initial fricative in the verb [-yaangul-] 'to cut' becomes a stop when it is preceded by the nasal prefix of class 9 in [ygaaygula] 'blacksmith'. In languages where the regular reflex of *-pàngod- does not start with a velar, this specific morphophonological change does not occur, as we discuss in more detail below.

Unconditioned velar reflexes of * $\mathbf{p}$ are not very widespread in Bantu, but they do occur in several languages, as shown on the isogloss map of Guthrie (1967: 70). Comparative data presented by Grégoire $(1975: 109,142)$ corroborate this: velar reflexes of *p are also attested in Lega (D25) spoken in the eastern DRC and in several B60-B70 languages, such as Ndumu (B63), Tio (B75) and Fumu (B77b), 
spoken in Gabon and Congo-Brazzaville. In the last three languages, the regular reflex of the locative noun prefix of class 16 is ya-, regularly corresponding to *pa-. Schadeberg (1989) demonstrates a similar correspondence between * $\mathbf{p}$ and the velar nasal $\boldsymbol{\eta}$ in Nyole (JE35) spoken in eastern Uganda. Mouandza (2002) reports $\mathbf{\gamma}$ as reflex of *p and yà- as $\mathrm{NP}_{16}$ in Iyaa (B73c), which is, just like Tio (B75) and Fumu (B77b), a Teke language from Congo-Brazzaville. In other words, velar reflexes of *p are scattered across the Bantu domain and can be considered the result of convergent evolution. Although unexpected at first sight, $\mathrm{\gamma}$ arises quite naturally from *p through a series of successive sound changes, as we discuss below. ${ }^{13}$

Although the voiced velar fricative $\mathrm{\gamma}$ is not particularly rare as a regular unconditioned intervocalic reflex of *p in Bantu, it only occurs in a restricted number of Kikongo varieties. Within the Kikongo dialect continuum, it is limited to Kintandu and a number of closely related eastern varieties spoken east of the Inkisi River in the Lower Congo Province of the DRC, such as Kimpangu, Kimbeko and Kinkanu, cf. (5e). In most other Kikongo varieties, the regular reflex is either $\mathbf{v}$ or $\mathbf{h}$, as shown in (5a-d), where the reflexes of the common Bantu verbs *-páng- 'act; make' and *-páan- 'to give' are presented in a number of Kikongo varieties.

\begin{tabular}{llll} 
& *-páng- & *-páan- & \\
\cline { 2 - 3 } a. Kimanyanga & -vánga & -vana & (Laman 1936) \\
Kisikongo & -vánga & -vàánà & (Ndonga Mfuwa 1995) \\
Kizombo & -váanga & -váaná & (Carter \& Makondekwa 1987) \\
Kimbata & -vanga & -vana & (KongoKing fieldwork 2012) \\
Kindibu & -vanga & -vana & (Coene 1960) \\
Kiyombe & -váángá & -váána & (De Grauwe 2009) \\
Iwoyo & -vàng-à & -vàn-à & (Mingas 1994) \\
Civili & väng' & vän & (I.LA.LOK 2008) \\
Cisundi & -vanga & -vaana & (Futi 2012) \\
b. Kiyombi & $/$ & kúßàánà & (Mabiala 1999) \\
Kisolongo & -ßanga & -ßana & (KongoKing fieldwork 2012) \\
c. Kisundi & $/$ & kuháánà & (Mabiala 1999) \\
Kibembe & $/$ & kuháánà & (Mabiala 1999) \\
Kihangala & $/$ & kuháánà & (Mabiala 1999) \\
d. Kilaari & -và:ngá & -gà:ná & (Jacquot 1982b) \\
& -hâna & & (Nsondé 1999)
\end{tabular}

13. We wish to thank one of the anonymous reviewers for having drawn our attention to these different sources reporting velar reflexes of * $p$ in Bantu. The same reviewer observed that according to a debated hypothesis, the speakers of Iyaa (B73c), situated in the Sibiti district east of Loango, would be descendants of the so-called Jaga who invaded the Kongo kingdom in the second half of the $16^{\text {th }}$ century (cf. Mouandza 1991: 11-14). Vansina (1966: 68) notes indeed that after the destruction of the Kongo kingdom 'Some [Jaga] went to Nsundi and founded a small but vigorous Yaka kingdom just east of Loango and south of the Kwilu Nyari Basin'. The glossonym Iyaa would be a deformation of Yaka. This hypothesis merits more research, especially if one takes into account that $y$ is a characteristic reflex of * $p$ in the Kongo languages spoken east of the Inkisi River, the wider area from where the Jaga would have originated. 
$\begin{array}{llll}\text { e. Kintandu } & \text {-gáang- } & \text {-gáán- } & \text { (Daeleman 1983) } \\ \text { Kimbeko } & \text {-yanga } & \text {-yaana } & \text { (KongoKing fieldwork 2012) } \\ \text { Kinkanu } & \text {-yanga } & \text {-yaana } & \text { (KongoKing fieldwork 2012) }\end{array}$

The varieties in (5a) manifest the most common unconditioned intervocalic reflex of * $\mathbf{p}$, i.e. $\mathbf{v}$. The varieties in $(5 \mathrm{~b})$ have retained what is probably the most archaic reflex of $* \mathbf{p}$ in at least a part of the Kikongo dialect continuum, i.e. $\boldsymbol{\beta}$. In the $17^{\text {th }}$ century Vocabularium Congense, a reflex of this verb is given, among others, under the Latin lemma efficio 'to do, make', i.e. cubhanga. The grapheme /bh/ stands here for the voiced bilabial fricative consonant (De Kind et al. 2012). The sound $\boldsymbol{\beta}$ is still found in Kisolongo (Lembe-Masiala 2007; Tavares 1915), ${ }^{14}$ as confirmed by KongoKing fieldwork in 2012, and in Kiyombi as spoken in Congo-Brazzaville (Mabiala 1999). The shift from the bilabial fricative $/ \boldsymbol{\beta} /$ to the labiodental fricative $/ \mathbf{v} /$ is common in the world's languages, and that is exactly what happened in most Kikongo varieties. The fact that both $/ \boldsymbol{\beta} /$ and $/ \mathbf{v} /$ originate in $* \mathbf{p}$ is still reflected in the morphophonological change $\boldsymbol{\beta} / \mathbf{v} \rightarrow \mathbf{p} / \mathbf{N}_{\mathbf{L}}$. Both $\boldsymbol{\beta}$ and $\mathbf{v}$ shift to $\mathbf{p}$ when these are preceded by a non-syllabic nasal, as evidenced by the class $9 / 10$ deverbative noun mpángu 'work, care, zeal, activity' (Laman 1936: 575), represented as npangú under the lemma opera 'work' in the Vocabularium Congense or by the conjugated first person singular ( $1 \mathrm{sg}$ ) perfective form npanguiri 'I have done' under the lemma effecio 'to do, make' (see also Van Wing \& Penders 1928: 198, 335). This often involves aspiration of the initial consonant, sometimes accompanied by the loss of the nasal prefix triggering this aspiration. This process is illustrated by the following imperatives in the Cisundi variety of Cabinda where the initial $\mathbf{v}$ of the verb stem is preceded by the $1 \mathrm{sg}$ object prefix N-: -vaana 'to give' vs. phaana 'give me'; -voonda 'to kill' vs. phoonda 'kill me' (Futi 2012: 32).

In a number of Kikongo varieties from Congo-Brazzaville, i.e. Kisundi, Kibembe, and Kihangala, $\mathbf{h}$ is a regular unconditioned intervocalic reflex of *p (Mabiala 1999), as shown in (5c). No reflex of *-páng- 'to act; make' was reported for any of these three varieties (Baka 1999; Jacquot 1962; Nkouanda 1997; Nsayi 1984; Philippson $\&$ Boungou 1999). In these varieties, the morphophonological change $\mathbf{h} \rightarrow \mathbf{g} / \mathbf{N}$ has not been observed. When the reflex $\mathbf{h}$ is preceded by a non-syllabic nasal, it is turned into $\left[\mathbf{p}^{\mathrm{h}}\right]$, as shown in the following Kisundi examples: lùhádì/phádì (cl. 11/10) 'squirrel(s)', lùhàkú/phàkú (cl. 11/10) 'fish-hook(s)', phúkúmúnú (cl. 9) 'temptation, seduction' (< kù-hùkùmúnà 'to deceive, seduce') (Baka 1999) for these languages.

In Kilaari, another variety from Congo-Brazzaville, the reflex of * $\mathbf{p}$ is either $\mathbf{g} / \mathbf{h}$ or $\mathbf{v}$, as shown in (5d). The most common reflex is $\mathbf{g} / \mathbf{h}$ whose phonetic realisation seems variable. Nsondé (1999) consistently notes $\mathbf{h}$, while Jacquot (1982a, b) consistently writes $\mathbf{g}$, specifying that this phoneme is phonetically realised in different ways. One of its realisations is as a 'soft voiceless dorsal fricative' ("fricative dorsale orale sourde douce"), i.e. [̊ํ] (Jacquot 1982a: 30), which is nearly the same as $\mathbf{h}$.

14. In Tavares (1915), the grapheme /v/ stands for [ $\beta]$ : 'Esta consoante [v], antes de $e, i, u$, é, em geral, mais labial que lábiodental' (p. 3). 
To sum up the comparative phonological evidence, *p has the following unconditioned reflexes in Kikongo: $\boldsymbol{\beta}, \mathbf{v}, \mathbf{h}, \stackrel{8}{\gamma}, \mathbf{\gamma}$. Assuming that Kikongo constitutes a historical subgroup, these phonetic outcomes can be seriated most economically as in (6) by postulating the intermediate proto-sound ${ }^{\circ} \Phi$.

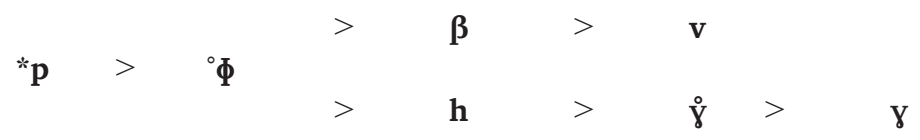

The unvoiced bilabial fricative $\Phi$ is attested neither in the present-day Kikongo dialect continuum, nor in the historical Kikongo sources. However, the lenition *p $>\boldsymbol{\phi}$ is not uncommon in Bantu (Guthrie 1967: 70). On the one hand, ${ }^{\circ} \phi$ can shift to $\boldsymbol{\beta}$ through simple voicing and subsequently to $\mathbf{v}$ by changing one more feature, i.e. place of articulation. On the other hand, the change from ${ }^{\circ} \boldsymbol{\Phi}$ to $\mathbf{h}$, which occurs widely in the languages of the world, can be motivated by acoustic similarity, rather than be seen as an articulatory process (Schadeberg 1989). The successive shifts to $\stackrel{\gamma}{ }$ and then $\mathrm{\gamma}$ are articulatory in nature and involve each time the changing of one single feature, i.e. the glottal fricative becomes velar and is subsequently voiced. The chain of changes $\mathbf{h}>\stackrel{\mathrm{\gamma}}{>}>\mathrm{y}$ seems all the more natural, if one takes into account the observation of Laman (1912: 29) that ' $\mathrm{H}$ is a guttural' and pronounced in certain varieties 'as a guttural mixed with a uvular $r$ or an indistinct $g$ sound $[\ldots]$ '. ${ }^{15}$ The label 'guttural' is no longer common in phonetics these days, but it used to refer to a rather broad category of 'back-of-the-mouth consonants' (Roach 1992: 51). Glottal, uvular and velar consonants are such sounds articulated near the back of the oral cavity. Hence, the tongue root only needs to be slightly advanced for the unvoiced glottal fricative $\mathbf{h}$ to become the unvoiced velar fricative $\mathrm{\gamma}$, as in Kilaari, and to be voiced afterwards to $\mathrm{y}$, as in the Kikongo varieties spoken east of the Inkisi River. The split seriation of *p reflexes through ${ }^{\circ} \Phi$ is possibly crucial for a better understanding of historical subgrouping within the Kikongo group, but this question goes beyond the scope of this article.

The examples in (7) show that $\mathrm{y}$ does also not occur as regular reflex of * $\mathbf{p}$ in those Bantu languages neighbouring Kikongo, which have ngangula or a phonetically similar term in their lexicon.

\begin{tabular}{llll} 
& *-páng- & *-páan- & \\
\cline { 2 - 4 } Kiyaka & -háángá & -hááná & (Ruttenberg 2000) \\
Kimbundu & -banga & -bana & (da Silva Maia 1961) \\
Umbundu & -panga & $/$ & (Le Guennec \& Valente 1972)
\end{tabular}

As a consequence, based on the diachronic phonological data presented here, ngangula cannot have originated in one of the non-Kikongo languages in which it occurs today. What is more, within the Kikongo dialect continuum, it can only have emerged in one specific region, i.e. east of the Inkisi River in the Lower Congo Province of the DRC. In Kintandu, Kimpangu, Kimbeko, and Kinkanu, both the morphophonological changes $\mathbf{N}+\mathbf{\gamma} \rightarrow \mathbf{m p}(\mathbf{h})$ and $\mathbf{N}+\mathbf{\gamma} \rightarrow \mathbf{n g}$ are observed in

15. We wish to thank one of the anonymous peer reviewers for having drawn our attention to this passage in Laman's grammar. 
post-nasal position. In Kintandu, the line of white clay put on the forehead and the temples as a sign of reconciliation is called luyéemba (Daeleman 1983: 341), a reflex of Proto-Bantu *-pémbá (Bastin et al. 2002). The white clay itself is called mpéemba, which is a reflex of the same noun stem, testifying to the shift $\mathbf{N}+\mathrm{\gamma} \rightarrow$ mp. On the other hand, ngeembá 'peace' derived from the verb -yeemb-, a reflex of "-pèmb- 'to appease', testifies to the shift $\mathbf{N}+\mathrm{\gamma} \rightarrow \mathbf{n g}$ (Daeleman 1983: 341). ${ }^{16} \mathrm{In}$ Kimbeko and Kinkanu, the term for kaolin is mpêmba (Van Damme 1998: 1139), while the imperative of the verb -yana 'to give' preceded by the $1 \mathrm{sg}$ object concord $\mathbf{N}$ - results in the form ngana (KongoKing fieldwork 2012). In other words, the consonant cluster * $\mathbf{m p}$ was maintained when it was inherited as such in the eastern Kikongo varieties. However, when the $y$ reflex of *p gets prenasalized in synchronic verbal conjugations or in recently derived nouns, $\mathrm{y}$ shifts to $\mathrm{g}$. This corroborates the fact that ngangula was not inherited from a pre-Kikongo ancestor, but is the outcome of a more recent deverbative derivation.

In terms of relative chronology, ngangula was thus created after eastern Kikongo varieties separated from the rest of the Kikongo dialect cluster. Kikongo languages did not inherit it from their most common recent ancestor, let alone from an even older language stage. It must have spread from Kikongo varieties spoken east of the Inkisi River to other Kikongo varieties and a limited number of neighbouring languages where it was adopted as a loanword that did not conform to the diachronic sound rules of the adopting languages. We even have historical evidence for this process of dialectal diffusion whereby ngangula competed with a cognate blacksmith term and eventually displaced it, i.e. mpangula derived from the same verb in the Kikongo variety spoken at the royal court in Mbanza Kongo. This is developed next.

As shown above (cf. last paragraph of Section 3), the Kintandu verb -gaangulhas cognates in other Kikongo varieties, e.g. -vàngula in Kimanyanga (Laman 1936: 1050) and -vaangúla in Kiyombe (De Grauwe 2009: 113). However, ngangula cannot be derived directly from these verbs, because when preceded by the nasal prefix of class $9, \mathbf{v}$ is transformed into $\mathbf{m p}$. Hence, -vangula would be turned into mpangula instead of ngangula. The deverbative noun mpangula is actually attested in the oldest available lexicographical Kikongo source. As can be seen in the extract from the Vocabularium Congense in Figure 2 below, in addition

16. In neighbouring Kiyaka (H31), the noun ngéémba 'peace, security, peacefulness' also occurs (Ruttenberg 2000: 151). Similarly, the noun for 'word, discourse', i.e. ngógo (Ruttenberg 2000: 152), also corresponds to a verb stem reconstructed with initial *p, i.e. "-póp- 'to speak' (Bastin et al. 2002), but according to regular sound correspondences (cf. 7), one would rather expect $\mathbf{h}$ in $\mathrm{C}_{2}$ instead of $\mathbf{g}$. What is more, $\mathbf{h}$ turns regularly into $\mathbf{p}^{\mathbf{h}}-$ not ng - when preceded by a non-syllabic nasal, e.g. luhúsu/phúsu (11/10) 'raffia fiber' (Van Den Eynde 1968: 35). This is not only the case in inherited vocabulary, as in the eastern Kikongo varieties, but also in productive verb conjugations, as can be observed in this Kiyaka example: thayaaku phéele makuta kúmi 'your brother has given me ten kuta' (Van Den Eynde 1968: 108). The verb phéele is the perfective form -hééle of the verb -héka 'to give' preceded by the 1 sg object concord $\mathbf{N}$-, which triggers the morphophonological change $\mathrm{h} \rightarrow \mathrm{ph} / \mathrm{N}$ _ before being absorbed. The fact that Kiyaka shares several phonologically irregular nouns, such as ngéémba and ngógo, with eastern Kikongo varieties is historically significant, but requires more research beyond the scope of this article. 
to mufúri a prata and quifula a prata, another compound term given under the lemma faber argentarius 'silversmith' is npangula anprata.

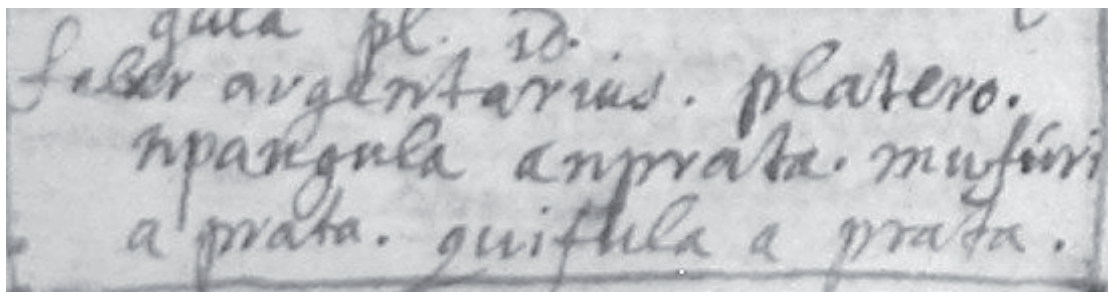

Figure 2: Lemma 'faber argentarius' in the Vocabularium Congense (Van Gheel 1652)

Van Wing and Penders (1928: 198) mention it under the lemma mpangula 'forgeron; smid', which Laman (1936: 576) subsequently copied in his dictionary, specifying that it is a term occurring only in the southern part of the Kikongo dialect cluster. On the same page in Laman's dictionary, one finds the lemmas mpàngula 'tooth chased according to the tradition', mpángula 'stake, stick at the top of the loom and attached in the roof', and mpängula 'a small sharp piece of wood fixed very closely above the incision in a palm tree to extract the wine in order to attach a gourd where the sap is flowing'. These three deverbative nouns are presented as regular Kimanyanga terms. All three seem to be derived from the verb -vàngula, the cognate of -gaangul- in Kintandu, the source verb of ngangula.

The fact that we find in the Vocabularium Congense both ngangula and npangula as terms for 'smith' not only proves that ngangula has indeed its origin in the common Bantu verb *-pàngud- 'to cut; separate', but also that both smith terms must have co-existed in the $17^{\text {th }}$ century Kikongo variety spoken at the court in Mbanza Kongo. In the $19^{\text {th }}$ century, ngangula had already displaced mpangula, since the latter is no longer found as a blacksmith term in the dictionary of Bentley (1887). It is only found with the meaning 'rope', possibly derived from the same verb -vàngula, i.e. 'something which is cut'. According to Troesch (1962: 98), mpangula is also the name of a traditional insignia in the kingdom of Soyo, where Kisolongo is spoken: 'L'insigne traditionnel est le bâton orné de clous à large tête, ma ntumba, ou à poignée taillée en figure de fétiche : nkoko, soit mpangula'.

\section{The smith's myth and Kongo political leadership}

That the Kongo use ngangula both to refer to a blacksmith and to a king or chief may seem odd on the face of it, but it is hardly surprising if one reckons that political power and blacksmithing are closely linked phenomena in many African societies, especially so in Bantu-speaking Central Africa (de Maret 1985; Dupré \& Pinçon 1997; Herbert 1993; Kriger 1999). According to De Heusch (1956), it is fire as an emblem of reproductive power that establishes a symbolic association between kingship and iron working. Herbert (1993: 132) argues that metallurgy and kingship share a common understanding of the nature, sources and control 
of power. Both are male-dominated activities that invoke paradigms of fertility and age for their accomplishment and that are interdependent but also potentially competitive. Hence, the royal connection with iron working was definitely more symbolic than economic, even though Kongo traditions have been read as an assertion of the primacy of the king over iron production (Herbert 1993: 145). Both early European witnesses and more recent scholars highlight the importance of blacksmiths, their craft, their tools and their products in Kongo kingship rites, such as the enthronement, and regalia (de Heusch 2000; Fromont 2011; Jadin 1968; Mac Gaffey 2000; Mertens 1942; Thornton 1992). In Kongo eyes, chiefs and smiths used to be one. They were initiated in similar circumstances, they might originate from the same clan, they respected the same food taboos and might wear the same bracelets (Mac Gaffey 1986: 67; Mertens 1942: 431-446).

The equation between blacksmith and king is old and possibly goes back to the origins of the Kongo kingdom. Wannyn (1961: 59) claims that 'le premier ntotela a été " maître de forges ", sinon forgeron', but hastens to add that iron working never was the exclusive right of the king or nobility. Traditions collected at the court of King Pedro IV (ruled 1694-1718) indeed present the founder as a blacksmith king and depict the ruling dynasty as offspring of a 'wise and skilful blacksmith' (Thornton 1993: 191). Cavazzi mentions in his posthumously published Istorica descrizione de tre regni Congo, Matamba ed Angola (1687), of which earlier drafts date back to 1665 (Randles 1968: 73), that one of the first Kongo kings was a blacksmith (Thornton 2011a).

In his article on Kongo regalia between 1491 and 1895, Thornton (1992) discusses several historical testimonies highlighting the significance of the blacksmith imagery. The earliest reference to the blacksmith in royal rites is to be found in a testimony from 1622 on the burial of King Alvaro II and the coronation of his successor King Pedro II between 5 and 27 May 1622 by the Portuguese Jesuit Mateus Cardoso (cf. Brásio 1952-1988: vol. XV, 489ff, translated by Thornton 1992: 57-58; see also Jadin 1968: 373ff). Cardoso describes a 'man playing a special whistle during the funeral of King Alvaro II, i.e. sembo ansuri (blacksmith's whistle), a royal symbol that sounded like a bird song' (Thornton 1992: 57-58). We note that the blacksmith was designated with the reflex of the common Bantu *-túdì, and not with the specific Kongo term ngangula. During the coronation ceremony of his successor, Cardoso describes three men seated around the royal drum, another very important form of regalia. Each of these men had two zundu or anvils. These great iron triangles with small rods were well tempered and, when struck, sounded like a blacksmith's hammer. These important blacksmith utensils were supposed to be the most ancient royal symbols, which could only be used by the king himself and by the duke of Mbata. After having been crowned with the white, cap-like mpu, the new king was invested with the simba, an iron chain with iron tassels hanging from it, which was placed around his neck. This insignia was also an ancient item, which could only be worn by the King, the Mwene Vunda (an official who played an important role in the selection and coronation of the kings) and the duke of Mbata. Another royal symbol evoking blacksmithing was an iron bracelet with gold workings, known as the malunga or bracelet of authority, which was placed on his right arm. The king was told that this iron bracelet was whole and entire as was the 
kingdom, and was made of iron as was the kingdom in its strength, hence it was called 'Congo riactari', or Kongo of iron. All these iron insignia endowed the king with the metaphor of the blacksmith as a conciliating and 'generous figure who settles disputes amicably', in accordance with the Central African 'smith's myth' (de Maret 1980, 1985).

According to Thornton (1992: 58), referring to another historical account by Mateus Cardoso, i.e. História do reino do Congo (edited by Brásio 1969) ${ }^{17}$, 'the blacksmith imagery was generally described as old and venerable, and was often handled by or worn equally by the other great nobles of the court: the Mwene Vunda and the duke of Mbata. Thus the blacksmith concept was also associated with rights of the other nobility, reminders of the structure of the kingdom as an elective monarchy, and the urge for paternal rule. Yet in the speech concerning Kongo's conquest, it was a blacksmith figure who was defeated by the first king and became the origin of the office of Mwene Vunda'. The conqueror image of the king was clearly predominant at the time of Pedro II's coronation.

This was no longer the case about a century later, following a long period of civil wars within the Kongo kingdom. Referring to a historical account attributed to Francesco da Pavia ${ }^{18}$, Thornton (1993: 191) writes that a 'memorial of about 1710 originating in Pedro IV's court described the royal family as descendants of a "wise and skilful blacksmith" who "gathered the Congolese People as their arbitrator of their differences and suits".' Pedro IV (ruled 1694-1718) was the king who restored the kingdom after the civil wars of the second half of the 17 th century and the Antonian movement, which reacted against this protracted warfare and was led by Beatriz Kimpa Vita who claimed to be an incarnation of Saint Anthony (Thornton 1983, 1998). Thornton (1993: 196) argues that 'his rule was characterized by compromise and negotiation, coupled with only minimal use of force. He seems to have agreed to an arrangement whereby power was shared alternately between the two most important contending families, the Kimulaza and Kimpanzu, with his own family, the Agua Rosada, withdrawing to the mountain fortress of Kibangu to serve as arbitrators.'

This link between Kongo leadership and blacksmithing continued until far into the $20^{\text {th }}$ century, as seen from the anthropological work of Mertens (1942) on 'crowned chiefs' amongst the Kongo people living east of the Inkisi River. He describes in much detail the fundamental role blacksmiths play in the selection and investment of chiefs as well as in their burial and in other chiefly cults and rites (see also de Heusch 1975). Similarly, Laman (1957: 146) describes how ngangula was invoked throughout the coronation of a new chief among the Basundi by singing: 'Eh, Ngangula (skilful in smithing), you have been crowned, you have been blessed. Eh, Ngangula, should you forget the prohibitions, do you see them, Ngangula?'. See also Herbert (1993: 136-144) for a discussion of the role of smiths in investiture rites among the Kongo and neighbouring people.

17. According to Bontinck (1972: 13), who produced an annotated French translation, the História do reino do Congo was composed during the reign of King Pedro II Afonso, i.e. between May 1622 and April 1624.

18. "Memoria sopra alcune cose che domanda il Re del Congo," s. d. [c. 1710], Archivio de Propaganda Fide, Scritture riferite nel Congressi, Africa, Congo, vol. 1, fol. 141. 
Given the key position of the blacksmith imagery in Kongo conceptualization of power, it can be safely assumed that the distribution of ngangula does not reflect the introduction and spread of metallurgy itself among Kongo people. This phenomenon can rather be linked with the more archaic blacksmith term *-túdì, which Kikongo inherited from a much older ancestor. The latter term is a very widespread agent noun among Bantu languages. It is derived from the common Bantu verb referring to the action of forging, i.e. "-túd-, whose basic meaning, as we have seen, is 'to hammer, to beat', (de Maret \& Nsuka-Nkutsi 1977; Klein-Arendt 2004). We also saw that the more recent blacksmith term ngangula spread through the Kikongo dialect cluster and substituted cognate terms in certain Kikongo varieties, but did not displace this older blacksmith term. Both terms continued to co-exist in most Kikongo varieties. The distribution and phonology of the common Bantu blacksmith term *-túdì across the entire Kongo domain suggest that the origin of iron working in the Lower Congo region is much older than the coinage of ngangula and even much older than the Kongo kingdom itself. This is in line with archaeological data, which situate the origins of iron smelting in the Lower Congo region around the first or second century of our era (Clist 2012; de Maret 1990: 453; Kanimba Misago 1991: 213). In contrast to ngangula, however, *-túdì is not a royal title, at least not amongst the Kongo. ${ }^{19}$

The term ngangula was thus not coined to designate a new metier. Its current-day distribution among Kikongo varieties and neighbouring languages is rather to be seen as the result of its metaphorical association with Kongo leadership. It has nothing to do with the spread of metallurgy itself. One can even wonder if the meaning 'smith' is anterior to its usage as a chiefly or royal title. Could a smith be primarily conceived as someone who cuts and separates? These actions are indeed part of the iron production process and instruments to do so belong to the basic equipment of African smiths. In many Bantu languages, the word for (cold) chisel is derived from a verb whose basic meaning is 'to cut' or 'to separate' (Klein-Arendt 2004: 171-174). The fact that smiths in West-Central Africa used such instruments is superbly illustrated in the aquarelle paintings included in Cavazzi's Missione evangelica nel Regno de Congo, a manuscript completed around 1668 and to be considered one of the first versions of his Istorica descrizione de tre regni Congo, Matamba ed Angola published in 1687. This text is widely known as the 'Araldi Manuscript' since it was owned by the Araldi family of Modena, Italy (Thornton 2011a). The paintings contain a wealth of ethnographic information and two of them represent the king of Ndongo, a small Mbundu kingdom to the south of Kongo, as a blacksmith (Bassani 1987). Both depict a number of blade-shaped objects which include, according to Maesen (1987: 97), scissors used to cut iron and belonging to the basic equipment of African smiths. Nonetheless, cutting is no doubt not central enough in the forging process for a smith to be called a 'cutter' or 'separator'. Bantu smith nouns are indeed commonly derived from verbs whose fundamental meaning

19. It does occur as a royal title among other Central African Bantuphone communities. The Italian Capuchin Giovanni Antonio Cavazzi da Montecuccolo ( $17^{\text {th }}$ century) reports, for instance, that the founder of the small kingdom of Ndongo is the legendary blacksmith king Angola Mussuri, who was believed to have come from neighbouring Kongo further north and to be a relative of its king (de Maret 1985: 73; Thornton 2011a). 
is 'to beat'. This is not only true for the common Bantu verb *-túd-, but also for less widespread forging verbs like East-Bantu *-pònd- whose basic meaning is 'to pound, stamp, beat' and Central-Bantu *-cámbud- which is also found with the meanings 'to hammer; whip; thresh' (Bastin et al. 2002). In his historical-comparative study of blacksmithing vocabulary in the Savanna Bantu languages, Klein-Arendt (2004: 108) plainly states that: 'Die Wörter für "schmieden" entstammen einem einzigen Grundkonzept, nämlich "schlagen"”. The semantic link with cutting can also not be accounted for by the fact that according to oral Kongo traditions, the knife was the first object to be forged (Balandier 1965: 100; Wannyn 1961: 60). In sum, the etymology of ngangula is difficult to reconcile with the fundamental meanings on which Bantu nouns for smith are commonly founded.

This kind of verb might produce, however, nouns designating political leaders. There even is another royal Kongo title that is possibly synonymous with ngangula, i.e. ntinu. According to Vansina (1990: 156), '[i]n Kongo and in the coastal area the $[\ldots]$ term ntinu derived from the verb "to cut" and its subsidiary meaning "to settle court cases"'. There is indeed a Proto-Bantu verb *-tín- reconstructed with the fundamental meaning 'to cut' (Bastin et al. 2002). It is therefore not inconceivable that ngangula originally referred to a political leader, i.e. the Kongo king or one of his forebears, and was only later on metaphorically associated with the blacksmith who is also considered as a personality settling disputes (de Maret 1980, 1985).

\section{The origins of Kongo kingship}

The origins of the Kongo kingdom are a much-debated issue. There are two main origin hypotheses, which Vansina (1963) discusses in a short but influential article. He argues himself in favour of the hypothesis that situates the origin of the kingdom's founders north of the Congo River in the current-day Mayombe region, more precisely close to the sources of the Shiloango River. A small state called Bungu, also spelled Vungu or Bungo, existed there. The Belgian Redemptorist historian Cuvelier (1941: 291) was the first to advance this northern origin hypothesis on the basis of the travel records of the Italian Capuchin Girolamo da Montesarchio $(1650 \mathrm{~s} / 1660 \mathrm{~s})^{20}$ and the historical account História do reino do Congo (1620s). In an alternative and older scenario, the Kongo kingdom was founded by conquerors who subjugated the autochthonous populations commonly recognized as Ambundu and came from a region known as Kongo dia Nlaza between the Inkisi and Kwango Rivers. Ravenstein (1901) and Van Wing (1921: 17-20), amongst others, supported this eastern origin hypothesis on the account of testimonies provided by Cavazzi (1687) and the Portuguese historians Cadornega (1680) (Delgado 1972) and Paiva Manso (1877). Also, historical traditions of Kongo people living east of the Inkisi River situate the origins of their ancestors in the Kwango (Van Wing 1921: 18).

Vansina (1963) discounts this eastern origin in favour of the northern origin discussed above. In his synthesis article on the origins and early history of the Kongo Kingdom, Thornton (2001) does not contest Vansina's rejection of an eastern origin,

20. These travel accounts were translated in French by Bouveignes and Cuvelier (1951) and edited in the original Italian version by Piazza (1976). 
although he also recognizes the existence of the "Seven Kingdoms of Kongo dia Nlaza" (Thornton 2001: 112). ${ }^{21}$

We argued in this article, on historical linguistic grounds, that ngangula can only have originated in one specific region of the Kongo, i.e. east of the Inkisi River. If the term's spread is indeed linked with Kongo kingship, rather than with the art of blacksmithing itself, could its origin then be indicative of the source of Kongo kingship itself? In other words, could the founders of the Kongo kingdom have come from the area east of the Inkisi? Obviously, just like one swallow does not make a summer, the debate on the origins of the Kongo kingdom cannot be concluded on the basis of one king's title. Moreover, the origin of this title does not necessarily reflect the origin of the king itself or a dynasty of kings, as it may rather hint at the source of certain ideas about kingship. The titles Kaiser and Czar, for example, indicate that Germans and Russians modeled their leadership at some point in time in the image of Roman emperors rather than that they originated in Rome. Furthermore, given that ngangula and its cognate npangula still co-occur in the Vocabularium Congense possibly implies that the spread of ngangula is linked with a historical event that happened much later than the foundation of the kingdom. However, this is not necessarily so, given that npangula may have been an archaism that was documented just in time, i.e. before it vanished for good. Finally, it needs to be reckoned that the origins of the Kongo kingdom need not be unilateral. Kingship or ideas on kingship do not necessarily originate in one specific region. Different political traditions may have blended into a new concept of leadership on which the Kongo kingdom was founded. In this regard, it is rather interesting to note that the already mentioned royal title ntinu possibly originated in the western part of the Kongo. According to Laman (1936: 974), -tin- 'to cut' is a verb restricted to western Kongo varieties. Do the royal Kongo titles ntinu and ngangula represent the merger of western and eastern political leadership traditions from which Kongo kingship arose? We believe that our historical linguistic conclusions allow for a reopening of the debate on the (unilateral) origins of Kongo kingship itself and to reconsider, at least, the plausibility of the eastern origin hypothesis discarded by Cuvelier (1941) and Vansina (1963).

In this regard, it is highly relevant that during his travels in 1650 through the eastern part of the kingdom and beyond Kongo's eastern borders, Girolamo da Montesarchio met, at a place called Elemba, a ruler who gave himself the title 'Grandfather of the King of Kongo' (Bouveignes \& Cuvelier 1951: 113; Piazza 1976: 218). In a report of September 7, 1619, Mateus Cardoso had already attributed the same title, i.e. Avô del Rey de Congo, to the duke of Mbata (Bontinck 1972: 89; Brásio 1952-1988: vol. VI, 376). Moreover, Cardoso wrote that the lords of Mbata addressed the Kongo kings as cotecolos (Brásio 1969: 48), which should be read as ntecolo or ntekolo 'grandchildren' (Bontinck 1972: 89; Thornton 2001: 110). Cavazzi (1687: 263) also reports this specific title for the duke of Mbata (Piazza 1976: 218). He actually notes that the title of 'Grandfathers of the King of Kongo' was attributed to the descendants of Nsaku Lau, father of the bride of Nimi a Nzima, himself father of Lukeni lua Nimi or Ntinu Wene, who is traditionally seen as the founder of Kongo. They would have been granted this title after they eventually

21. This was an ancient federation of small polities east of the Inkisi to the Kwango. 
submitted to Kongo's authority. As paraphrased by Thornton (2001: 110), Nsaku Lau "took possession of Batta" which "in those days was a kingdom," and which he maintained in considerable independence (Cavazzi 1687: 105). This is in line with $16^{\text {th }}$ century traditions which stress the voluntary alliance of Mbata with Kongo in order to insure succession in a single lineage (Thornton 2001: 110). All this adds to the crucial role the area east of the Inkisi River played in the genesis of the Kongo kingdom. This continued to be reflected in the privileges, which Mbata leaders enjoyed with respect to the selection and enthronement of Kongo kings, as shown above when discussing the burial of King Alvaro II and the coronation of his successor King Pedro II in 1622.

The imagery of the alliance of Kongo with Mbata as an independent kingdom, as the emergence of the Kongo kingdom was presented in the $16^{\text {th }}$ century, may have been a way of coping with new power relations. It is not unimaginable that Lukeni lua Nimi was not the founder of the Kongo kingdom itself, but simply the initiator of a new royal dynasty with its origins north of the Congo River, i.e. in Vungu. The emphasis put on the voluntary alliance with Mbata during the $16^{\text {th }}$ century may then have been a way of reconciliation with an earlier ruling dynasty having its origins east of the Inkisi. In the $17^{\text {th }}$ century, once the ruling dynasty was well established, the conquest metaphor could start to develop, although not without recognizing Mbata as a province which first had a lot of independence and then became an honoured subordinate (Thornton 2001: 110).

\section{Conclusions}

The historical-comparative linguistic evidence presented in this article allows us to claim that the term ngangula is historically derived from the common Bantu verb which has been reconstructed as *-pàngod- 'to cut; separate' and whose reflex in Kintandu and lesser-known eastern Kongo varieties is -yaangul-. This verb is not to be confounded with -yáángúl- 'to undo, mutilate, ruin', the separative derivation of the verb -gáang- 'to make, do', a reflex of the common Bantu verb reconstructed as *-páng- 'act; make'. Cognate reflexes of *-pàngod- also exist in other Kikongo varieties, but with another initial consonant. Within the Kongo dialect continuum, the sound change ${ }^{*} \mathbf{p}>\boldsymbol{\gamma}$ is distinctive of the varieties spoken east of the Inkisi River. As a consequence, the possible geographical origins of ngangula can be narrowed down to this specific region of the wider Kongo area.

These historical-comparative linguistic findings on the etymology and the geographical origin of this term would be trivial, were it not that ngangula a Kongo is a traditional title of the king of Kongo. It is commonly translated as the 'blacksmith of Kongo'. The term ngangula is indeed found with this translation equivalent in most lexicographical Kongo sources since the Vocabularium Congense, the oldest Bantu dictionary. The fact that Kongo people referred to blacksmiths and their supreme leader with the same term ties in well with the symbolic association between political power and blacksmithing that is very common in Central African societies. Nevertheless, the diachronic semantics of ngangula burdens us with a chicken-and-egg problem. Bantu verbs for smithing, and by extension deverbative agent nouns refering to the smith, generally originate in verbs meaning 'to beat', 
and not in verbs meaning 'to cut', as is the case with ngangula. Such an etymology is found, however, with terms designating political leaders, like for instance that other royal Kongo title ntinu. One may thus wonder which came first, the blacksmith meaning or the association with political power? We have argued in favour of political power.

Moreover, the eastern provenance of ngangula gives new credibility to the earlier but discarded hypothesis situating the origins of the Kongo kingdom somewhere between the Inkisi and Kwango Rivers. To be sure, historical-linguistic evidence consisting of one individual term does not suffice to settle the long-standing debate on Kongo origins. Nevertheless, the fact that this specific royal title originates from an area which can be linked with the ancient federation of small polities known as Kongo dia Nlaza does call for a reopening of the debate on the origins of the Kongo kingdom. And if not on the genesis of the kingdom itself, it at least calls for a new reflection on the traditions that contributed to the way Kongo kingship was conceived through time. Moreover, it is not necessarily a question of either northern or eastern origins. The possibility of multilateral origins should be envisaged. The traditions favouring eastern and northern origins might well pertain to different building layers in the development of the Kongo kingdom. Would it not be conceivable that traditions situating the kingdom's homeland north of the Congo River simply concern the home of a given dynasty? Rather than relating to the actual beginning of the kingdom itself, those traditions could simply relate to a new royal line initiated by Lukeni lua Nimi, traditionally considered to be the founder of the kingdom. The origin traditions referring to the upper Kwango area might then bear upon an earlier phase in the constitution of the kingdom. In any event, we hope to have shown that the careful historical-comparative linguistic study of more royal Kongo vocabulary will help us to rewrite the early history of the Kongo kingdom.

\section{References}

Andersen, H. 1988. 'Center and periphery: adoption, diffusion, and spread'. In J. Fisiak (ed.), Historical Dialectology: Regional and Social, 39-83. Berlin; New York; Amsterdam: Mouton de Gruyter.

Anonyme. 1890. Dictionnaire français-fiote, dialecte du Kakongo, par les missionnaires de la Congrégation du Saint-Esprit et du Saint-Coeur de Marie, Mission de Landana, Préfecture apostolique du Bas-Congo. Paris: Librairie orientale et américaine; Maisonneuve frères, éditeurs.

Baka, J. 1992. Essai de description du tso:tso, parler ko:ngo du Nord de l'Angola. Brussels: Université libre de Bruxelles, mémoire de licence spéciale.

—, 1999. Dictionnaire fondamental kisuundi-français suivi d'un index français. Brazzaville: Centre pour l'Étude des Langues Congolaises, Université Marien Ngouabi (manuscrit non-publié).

Balandier, G. 1965. La Vie quotidienne au royaume de Kongo du XVI e au XVIII ${ }^{e}$ siècle. Paris: Hachette.

Bassani, E. 1987. 'Un cappuccino nell'Africa nera del seicento. I desegni dei Manoscritti Araldi del Padre Giovanni Antonio Cavazzi da Montecuccolo', Quaderni Poro 4: 1-93. 
Bastin, Y., A. Coupez, E. Mumba \& T.C. Schadeberg (eds) 2002. Bantu lexical reconstructions 3 / Reconstructions lexicales bantoues 3. Tervuren: Royal Museum for Central Africa, online database: http://linguistics.africamuseum. be/BLR3.html (last accessed September 4, 2012).

Bentley, W.H. 1887. Dictionary and Grammar of the Kongo language as spoken at San Salvador, the Ancient Capital of the Old Kongo empire, West Africa. London: Baptist Missionary Society and Trübner \& Co.

Bittremieux, L. 1922. Mayombsch idioticon, Deel II. Gent: Erasmus.

Blench, R. 2009. 'Bananas and Plantains in Africa: Re-interpreting the linguistic evidence', Ethnobotany Research \& Applications 7: 363-380.

Bontinck, F. 1972. Histoire du royaume Kongo (c. 1624). Traduction annotée du Ms. 8080 de la Bibliothèque nationale de Lisbonne. Louvain; Paris: Éditions Nauwelaerts - Béatrice Nauwelaerts.

Bostoen, K. 2005. Des mots et des pots en bantou. Une approche linguistique de l'histoire de la céramique en Afrique (Schriften zur Afrikanistik - Research in African Studies 9). Frankfurt: Peter Lang.

-, 2006-2007. 'Pearl millet in early Bantu speech communities in Central Africa: A reconsideration of the lexical evidence', Afrika und Übersee 89: 183-213 [published in 2010].

—, 2007. 'Pots, words and the Bantu problem: On lexical reconstruction and early African history', Journal of African History 48: 173-199.

Bouka, L.Y. 1989. Eléments de description du kaamba, parler bantou de la République Populaire du Congo (Groupe Koongo, H17b). Bruxelles: Université libre de Bruxelles, mémoire de licence spéciale.

Bouveignes, O. \& J. Cuvelier. 1951. Jérôme de Montesarchio : apôtre du vieux Congo. Namur: Grands Lacs.

Brásio, A. (ed.) 1952-1988. Monumenta missionária Africana. Africa Ocidental. Lisboa: Agência Geral do Ultramar/Academia portuguesa da Historia.

-, (ed.) 1969. História do reino do Congo (Ms. 8080 da Biblioteca Nacional de Lisboa). Lisboa: Centro de Estudos Históricos Ultramarinos.

Carter, H. \& J. Makondekwa. 1987. Kongo language course: Maloongi makikoongo, a course in the dialect of Zoombo, Northern Angola. Madison: African Studies Program, University of Wisconsin.

Cavazzi da Montecuccolo, G.A. 1687. Istorica descrizione de’ tre regni Congo, Matamba ed Angola. Bologna: Giacomo Monti.

Clist, B. 2012. 'Vers une réduction des préjugés et la fonte des antagonismes : un bilan de l'expansion de la métallurgie du fer en Afrique sud-saharienne', Journal of African Archaeology 10: 71-84.

Coene, A. 1960. Kikongo: Notions grammaticales. Vocabulaire Français-Kikongo, Néerlandais-Latin. Tumba: Imprimerie Maison Catholique.

Cuvelier, J. 1941. Het oud-koninkrijk Kongo: oorsprong, ontdekking en eerste christianisatie van het oude rijk, en regeering van Kongo's grootsten koning Affonso Mvemba Nzinga (†1541). Brugge: Desclée De Brouwer.

da Silva Maia, A. 1961. Dicionário complementar português-kimbundu-kikongo, linguas nativas do centro e norte de Angola. Cucujães (Angola): Tipografia das Missões. 
Daeleman, J. 1983. 'Les réflexes du proto-bantu en ntandu (dialecte koongo)'. In C. Faïk-Nzuji Madiya \& E. Sulzmann (eds), Mélanges de culture et de linguistique africaines publiés à la mémoire de Leo Stappers, 331-397. Berlin: Dietrich Reimer Verlag.

De Grauwe, J. 2009. Lexique yoómbe-français, avec index français-yoómbe (bantu H16c) (Tervuren Series for African Language Documentation and Description). Tervuren: Royal Museum for Central Africa.

de Heusch, L. 1956. 'Le symbolisme du forgeron en Afrique', Reflets $d u$ Monde 10: 57-70.

—, 1975. 'Le roi, le forgeron et les premiers hommes dans l'ancienne société kongo'. Systèmes de pensée en Afrique noire 1: 165-179.

—, 2000. Le roi de Kongo et les monstres sacrés. Mythes et rites bantous III (Les Essais). Paris: Gallimard.

De Kind, J., G.-M. de Schryver \& K. Bostoen. 2012. 'Pushing back the origin of Bantu lexicography: the Vocabularium Congense of 1652, 1928, 2012', Lexikos 22: 159-194.

de Luna, K.M. 2008. Collecting Food, Cultivating Persons: Wild Resource Use in Central African Political Culture, c. 1000 B.C.E. to c. 1900 C.E. Evanston: Northwestern University, PhD thesis.

—, 2012. 'Hunting Reputations: Talent, Individualism, and Community-Building in Precolonial South Central Africa', Journal of African History 53: 279-299.

de Luna, K.M., J.B. Fleisher \& S.K. McIntosh. 2012. 'Thinking Across the African Past: Interdisciplinarity and Early History', African Archaeological Review 29: 75-94.

de Maret, P. 1980. 'Ceux qui jouent avec le feu: la place du forgeron en Afrique centrale', Africa: Journal of the International African Institute 50: 263-279.

—, 1985. 'The smith's myth and the origin of leadership in Central Africa'. In R. Haaland \& P.L. Shinnie (eds), African iron working, ancient and traditional. Oslo; New York: Norwegian University Press; OUP.

—, 1990. 'Le “néolithique” et l'Age du Fer Ancien dans le sud-ouest de l'Afrique Centrale'. In R. Lanfranchi \& D. Schwartz (eds), Paysages quaternaires de l'Afrique Centrale Atlantique, 447-457. Paris: ORSTOM.

de Maret, P. \& F. Nsuka-Nkutsi. 1977. 'History of Bantu metallurgy: some linguistic aspects', History in Africa 4: 43-56.

Delgado, J.M. (ed.) 1972. História geral das guerras angolanas (1680, tomo III) (António de Oliveira de Cadornega). Lisboa: Agência Geral do Ultramar.

Derouet, J. 1896. Dictionnaire français-fiote, dialecte vili. Loango: Imprimerie de la Mission Catholique.

Devisch, R. 1993. Weaving the threads of life: the Khita gyn-eco-logical healing cult among the Yaka. Chicago: University of Chicago Press.

Dimmendaal, G. 2011. Historical Linguistics and the Comparative Study of African Languages. Amsterdam; Philadelphia: John Benjamins.

Dupré, M.-C. \& B. Pinçon. 1997. Métallurgie et politique en Afrique centrale. Deux mille ans de vestiges sur les plateaux Batéké. Gabon, Congo, Zaïre. Paris: Karthala. 
Ehret, C. 1967. 'Cattle-keeping and Milking in Eastern and Southern African History: the Linguistic Evidence', Journal of African History 8: 1-17.

-, 1974. Agricultural History in Central and Southern Africa, ca. 1000 B.C. to A.D. 500', Transafrican Journal of History 4: 1-25.

—, 2001. 'The Establishment of Iron-working in Eastern, Central, and Southern Africa: Linguistic Inferences on Technological History', Sprache und Geschichte in Afrika 16/17: 125-175.

Fehderau, H.W. 1992. Dictionnaire kituba (kikongo ya leta)-anglais-français et vocabulaire français-kituba. Kinshasa: Editions CEDI.

Fodor, I. \& L. Magyar. 1983. Introduction to the history of Umbundu: L. Magyar's records (1859) and the later sources. Hamburg; Budapest: Helmut Buske; Akadémia Kiadó.

Fromont, C. 2011. 'Dance, Image, Myth, and Conversion in the Kingdom of the Kongo, 1500-1800', African Arts 44: 52-63.

Futi, J.M. 2012. Essai de Morphologie Lexicale du Cisuundi du Cabinda (Angola). Paris: L'Harmattan.

Grégoire, C. 1975. Les locatifs en bantu (Annales Sciences humaines 83). Tervuren: Musée royal de l'Afrique centrale.

—, 1976. 'Le champ sémantique du thème bantu *-bánjá', African Languages/ Langues Africaines 2: 1-12.

Guinness, H.G. 1882. Grammar of the Congo language as spoken two hundred years ago, translated from the Latin of Brusciotto. London: Hodder \& Stoughton.

Guthrie, M. 1967. Comparative Bantu. An introduction to the comparative linguistics and prehistory of the Bantu languages. Volume 1. London: Gregg.

-, 1970. Comparative Bantu. An introduction to the Comparative Linguistics and Prehistory of the Bantu Languages. Volume 3. London: Gregg.

Herbert, E.W. 1993. Iron, gender, and power: rituals of transformation in African societies. Bloomington, IN: Indiana University Press.

Hildebrand, P.J.R. 1940. Le martyr Georges de Geel et les débuts de la mission du Congo (1645-1652). Anvers: Archives des Capucins.

I.LA.LOK. 2008. Dictionnaire vili-français. Mpisukulu bi kum' bi tshi vili ku tshi mputu. Paris: L'Harmattan.

Jacquot, A. 1962. 'Notes sur la phonologie du beembe (Congo)', Journal of African Languages 1: 232-242.

-, 1982a. Étude descriptive de la langue laadi. Lille: Atelier National de Reproduction des Thèses.

—, 1982b. Lexique laadi (koongo) (Oralité-documents 3). Paris: Société d'études linguistiques et anthropologiques de France; Office de la recherche scientifique et technique outre-mer.

Jadin, L. 1968. Relations sur le Congo et l'Angola tirées des archives de la Compagnie de Jésus 1621-1631. Bruxelles; Rome: Academia Belgica.

Janzen, J.M. \& W. Arkinstall. 1978. The quest for therapy in Lower Zaire. Berkeley; London: University of California Press.

Kanimba Misago, C. 1991. 'L'Age du Fer Ancien : Zaïre'. In R. Lanfranchi \& B. Clist (eds), Aux origines de l'Afrique centrale, 212-217. Paris: Centres Culturels Français de l'Afrique Centrale / Sépia. 
Klein-Arendt, R. 2004. Dietraditionellen Eisenhandwerkeder Savannen-Bantu: eine sprachhistorische Rekonstruktion auf lexikalischer Grundlage (Schriften zur Afrikanistik = Research in African studies 8). Frankfurt am Main; New York: Peter Lang.

Klieman, K.A. 2003. "The Pygmies were our compass": Bantu and Batwa in the history of west central Africa, early times to c. 1900 C.E (Social history of Africa). Portsmouth, NH: Heinemann.

Kriger, C.E. 1999. Pride of men: ironworking in 19th century West Central Africa. Oxford: James Currey.

Laman, K.E. 1912. Grammar of the Kongo language (Kikongo). New York: Christian Alliance Publishers.

—, 1936. Dictionnaire kikongo-français, avec une étude phonétique décrivant les dialectes les plus importants de la langue dite kikongo. Bruxelles: Librairie Falk.

—, 1957. The Kongo II (Studia Ethnographica Upsaliensia 8). Uppsala: Almqvist \& Wiksells.

Laman, K.E. \& C. Meinhof. 1928-29. 'An essay in Kongo phonology', Zeitschrift für Eingeborenen-Sprachen 19: 12-40.

Le Guennec, G. \& J.F. Valente. 1972. Dicionário português-umbundu. Luanda: Instituto de Investigação Cientifíca de Angola.

Lembe-Masiala, N. 2007. Le Káandu chez les Basolongo du Bas-Congo (RDC). Gand: Université de Gand, thèse de doctorat.

Loëmbe, G. 2005. Parlons Vili: Langue et culture de Loango. Paris: L'Harmattan.

Mabiala, J.-N. 1999. Phonologie comparative et historique du koongo. Lyon: Université Lumiere Lyon 2, thèse de doctorat.

Mac Gaffey, W. 1986. Religion and society in central Africa: the BaKongo of lower Zaire. Chicago: University of Chicago Press.

Mac Gaffey, W. 2000. Kongo political culture: the conceptual challenge of the particular. Bloomington: Indiana University Press.

Maesen, A. 1987. 'Notice relative à l'inventaire ethnographique des dessins du manuscrit', Quaderni Poro 4: 95-102.

Marichelle, C. 1912. Dictionnaire français-vili. Loango: Impr. de la Mission.

Mertens, J. 1942. Les chefs couronnés chez les Ba Kongo orientaux : étude de régime successoral. Brussels: G. van Campenhout.

Mfoutou, J.-A. 1985. Esquisse phonologique du kidoondo: un dialecte koongo de la République Populaire du Congo. Brazzaville: Université Marien Ngouabi, mémoire de DES.

Mingas, A.A. 1994. Étude grammaticale de l'iwoyo (Angola). Paris: Université René Descartes Paris 5, thèse de doctorat.

Monnier, L. 1966. 'Note sur les structures politiques de l'ancien Royaume de Kongo avant l'arrivée des Portugais', Genève-Afrique: Acta Africana 5: 7-55.

Mouandza, J.-D. 1991. Esquisse phonologique du iyaa (Parler bantu du Congo). Brazzaville: Université Marien Ngouabi, mémoire de DES.

—, 2002. Éléments de description du iyaa (parler bantu du Congo-Brazzaville). Nice: Université de Nice Sophia Antipolis, thèse de doctorat. 
N'sondé, S.R. 2012. Du sens originel de Nzambi a Mpúngu. Herméneutique de la catéchèse et de la tradition orale koongo : le champ mbi du sacré ou de l'intime. Paris 1: thèse de doctorat.

Ndamba, J. 1977. Syntagme nominal et groupe nominal en vili (langue bantou du Congo). Paris: Université Sorbonne Nouvelle Paris 3, thèse de doctorat.

Ndonda Tshiyayi, O. 2004-2005. 'La désignation du forgeron dans les langues kongo et apparentées. Essai d'une étude motivationnelle', Annales de la Faculté des Lettres et Sciences 5-6: 25-39.

Ndonga Mfuwa, M. 1995. Systématique grammaticale du kisikongo (Angola). Paris: Université René Descartes Paris 5, thèse de doctorat.

Ngoie-Ngalla, D. 1989. Les sociétes et les civilisations de la vallée du Niari dans le complexe ethnique Koongo; XVIe - XVIIe siècle: Formes et niveau d'intégration. Paris: Université Panthéon-Sorbonne Paris 1, thèse de doctorat.

Nkouanda, B.P. 1997. Description phonologique du kiga:ngala, parler bantou du Congo (Groupe H). Brazzaville: Université Marien Ngouabi, mémoire de maîtrise.

Nsayi, B. 1984. Approche du kibeembe:première et deuxième articulation. Paris: Université René Descartes Paris 5, thèse de doctorat.

Nsondé, J.d.D. 1995. Langues, culture et histoire Koongo aux XVIIe et XVIIIe siècles, à travers les documents linguistiques (Collection racines du présent). Paris: L'Harmattan.

—, 1999. Parlons kikôngo. Le lâri de Brazzaville et sa culture. Paris: l'Harmattan.

—, 2011. Parlons kimbundu. Langue de l'Angola. Paris: l'Harmattan.

Paiva Manso, L.M.J. 1877. Historia do Congo : obra posthuma (documentos). Lisboa: Typographia da Academia.

Philippson, G. \& S. Bahuchet. 1994-1995. 'Cultivated crops and Bantu migrations in central and eastern Africa: A linguistic approach', Azania 29-30: 103-120.

Philippson, G. \& P. Boungou. 1999. 'Éléments de tonologie beembe (H.11)'. In J.A. Blanchon \& D. Creissels (eds.), Issues in Bantu tonology, 83-107. Köln: Rüdiger Köppe.

Piazza, C. (ed.) 1976. La prefettura apostolica del Congo alla metà del XVII secolo. La relazione inedita di Girolamo da Montesarchio. Milano: Dott. A. Giuffrè, Università di Trieste.

Plancquaert, M. 1971. Les Yaka. Essai d'histoire. Tervuren: Musée royal de l'Afrique centrale.

Randles, W.G.L. 1968. L'Ancien royaume du Congo des origines à la fin du XIXe siècle (Civilisations et sociétés, 14). Paris, La Haye,: Mouton.

Ravenstein, E.G. (ed.) 1901. The strange adventures of Andrew Battell, of Leigh, in Angola and the adjoining regions. Reprinted from "Purchas his pilgrimes". London: Printed for the Hakluyt Society.

Ricquier, B. 2013. Porridge Deconstructed: A Comparative Linguistic Approach to the History of Staple Starch Food Preparations in Bantuphone Africa. Bruxelles: Université Libre de Bruxelles, PhD thesis.

Ricquier, B. \& K. Bostoen. 2008. 'Resolving phonological variability in Bantu lexical reconstructions: the case of 'to bake in ashes', Africana Linguistica 14: $109-150$. 
Roach, P. 1992. Introducing Phonetics (Penguin English Linguistics). London: Penguin.

Ruttenberg, P. 2000. Lexique yaka-francais, français-yaka (Languages of the World Dictionaries). München: Lincom Europa.

Schadeberg, T.C. 1989. 'The velar nasal in Nyole (E. 35)', Annales Aequatoria 10: $168-180$.

—, 2003. 'Derivation'. In D. Nurse \& G. Philippson (eds), The Bantu Languages, 71-89. London; New York: Routledge.

Schoenbrun, D.L. 1998. A green place, a good place: agrarian change, gender, and social identity in the Great Lakes region to the 15th century (Social history of Africa). Portsmouth: Heinemann.

Soret, A. 1959. Les Kongo nord-occidentaux. Paris: Presses universitaires de France.

Soysal, O. 2005. 'On the Origin of the Royal Title Tabarna/Labarna', Anatolica 31: 189-209.

Stephens, R. 2007. A History of Motherhood, Food Procurement and Politics in East-Central Uganda to the Nineteenth Century. Evanston, Illinois: Northwestern University, PhD thesis.

—, 2009. 'Lineage and Society in Precolonial Uganda', Journal of African History 50: 203-221.

Swartenbroeckx, P. 1973. Dictionnaire kikongo- et kituba-français (Publications Ceeba III). Bandundu: Ceeba.

Tavares, J.L. 1915. Gramática da língua do Congo (kikongo) (dialecto kisolongo). Luanda: Imprensa nacional da colónia de Angola.

Thornton, J.K. 1983. The Kingdom of Kongo: civil war and transition, 1641-1718. Madison: University of Wisconsin Press.

—, 1992. 'The Regalia of the Kingdom of Kongo, 1491-1895'. In E. Beumers \& P. Koloss (eds), Kings of Africa: Art and Authority in Central Africa, 56-63. Maastricht: Foundation Kings of Africa.

—, 1993. " "I Am the Subject of the King of Congo": African Political Ideology and the Haitian Revolution', Journal of World History 4: 181-214.

—, 1998. The Kongolese Saint Anthony: Dona Beatriz Kimpa Vita and the Antonian movement, 1684-1706. Cambridge (UK); New York: Cambridge University Press.

—, 2001. 'The origins and early history of the Kingdom of Kongo, c.1350-1550', International Journal of African Historical Studies 34: 89-120.

-, 2011a. Cavazzi, Missione Evangelica. http://www.bu.edu/afam/faculty/john thornton/cavazzi missione evangelica 2/

—, 2011b. Roboredo, Kikongo Sermon. http://www.bu.edu/afam/faculty/john thornton/roboredo kikongo sermon

Troesch, J. 1962. 'Le royaume de Soyo', Aequatoria 25: 95-100.

Van Damme, A. 1998. Beelden, maskers en intiatiepanelen bij de Nkanu en hun buren de Mbeko en de Lula. Socio-culturele context en stilistische analyse (Zone Kimvula, Congo). Gent: Universiteit Gent, doctoraatsthesis.

Van Den Eynde, K. 1968. Éléments de grammaire yaka : phonologie et morphologie flexionnelle. Kinshasa: Université Lovanium, Publications Universitaires. 
Van Gheel, J. 1652. Vocabularium Latinum, Hispanicum, e Congense. Ad Usum Missionariorû transmittendorû ad Regni Congo Missiones. Ms. Rome: National Central Library, Fundo Minori 1896, MS Varia 274.

Van Wing, J. 1921. Études Bakongo, Histoire et Sociologie. Bruxelles: Goemare.

-, 1938. Études Bakongo. II. Religion et Magie (Mémoires de l'Institut Royal Colonial Belge, Section des Sciences Morales et Politiques 9). Bruxelles: Librairie Falk fils.

—, 1959. Études Bakongo : sociologie, religion et magie. Brugge: Desclée De Brouwer.

Van Wing, J. and C. Penders. 1928. Le plus ancien dictionnaire bantu. Het oudste Bantu-Woordenboek. Vocabularium P. Georgii Gelensis. Louvain: J. Kuyl-Otto.

Vansina, J. 1962. 'Long-Distance Trade-Routes in Central Africa', Journal of African History 3: 375-390.

—, 1963. 'Notes sur l'origine du royaume de Kongo', Journal of African History 4: 33-38.

-, 1966. Kingdoms of the Savanna. Madison: University of Wisconsin Press.

—, 1974. 'The Dictionary and the Historian', History in Africa 1: 149-152.

-, 1990. Paths in the Rainforest: Toward a History of Political Tradition in Equatorial Africa. Madison: University of Wisconsin Press.

—, 2006. 'Linguistic Evidence for the Introduction of Ironworking in Bantu-Speaking Africa', History in Africa 33: 321-361.

-, 2009. 'Is a Journal of Method Still Necessary?', History in Africa 36: 421-438.

Visseq, A. 1889. Dictionnaire fiot ou dictionnaire de la langue du Congo. Paris: Maison-mère.

Volavka, Z. 1998. Crown and ritual: the royal insignia of Ngoyo. Toronto; London: University of Toronto Press.

Wannyn, R.L. 1961. L'art ancien du métal au Bas-Congo (Les Vieilles civilisations ouest africaines). Champles: Vieux Planquesaule.

\section{Authors' adresses}

Koen Bostoen

KongoKing Research Group

Ghent University

Université libre de Bruxelles

Rozier 44

9000 Gent

Belgium

Koen.Bostoen@UGent.be

Odjas Ndonga Tshiyayi

Département de Lettres et Civilisations africaines

Faculté des Lettres et des Sciences humaines

Université de Kinshasa

République démocratique du Congo

odjasndonda@yahoo.fr 
Gilles-Maurice de Schryver

KongoKing Research Group

Ghent University

Rozier 44

9000 Gent

Belgium

gillesmaurice.deschryver@UGent.be

Department of African Languages

University of Pretoria

South Africa

\section{Résumé}

Cet article offre une étude approfondie en linguistique historico-comparative sur l'origine et l'étymologie de ngangula. Ce terme est non seulement répandu dans la région du Bas-Congo pour forgeron, mais c'est aussi un titre royal traditionnel kongo qui atteste de l'importance de la métaphore du forgeron dans l'idéologie politique kongo. L'étymologie populaire veut que le terme ngangula soit lié à nganga, reconstruit *-gàngà en proto-bantu et généralement traduit par 'guérisseur'. Nous montrons ici que cette croyance largement partagée ne résiste pas à un examen approfondi. Nous montrons que le terme ngangula dérive plutôt du verbe *-pàngud- bien attesté en bantu et signifiant 'couper, séparer'. À partir de l'évidence diachronique d'un changement phonétique distinctif, nous pouvons même situer assez précisément l'origine du terme au sein du continuum dialectal kikongo. Sa source crédibilise à nouveau une hypothèse ancienne mais rejetée qui situait les origines du royaume kongo dans la partie orientale du Bas-Congo, quelque part entre les rivières Inkisi et Kwango. 
